\title{
Fiscal Decentralization and Economic Growth in OECD Countries: Is there a Relationship?
}

\author{
THUSHYANTHAN BASKARAN \\ LARS P. FELD
}

CESIFO WORKING PAPER NO. 2721

CAtegory 1: Public Finance

JULY 2009
An electronic version of the paper may be downloaded
- from the SSRN website: Www.SSRN.com
- from the RePEc website: Www.RePEc.org
- from the CESifo website: www.CESifo-group.org/wp




\title{
Fiscal Decentralization and Economic Growth in OECD Countries: Is there a Relationship?
}

\begin{abstract}
We study the relationship between fiscal decentralization and economic growth for 23 OECD countries from 1975 to 2001 by using new panel data on sub-federal tax autonomy. While initial estimations suggest that fiscal decentralization causes lower growth rates, we find that this result is not robust to alternative specifications. We also fail to obtain evidence for a negative relationship in a number of additional robustness checks. We thus conclude that fiscal decentralization is unrelated to economic growth.
\end{abstract}

JEL Code: H77, H73, H71, D78.

Keywords: fiscal federalism, sub-national fiscal autonomy, tax competition.

Thushyanthan Baskaran

Ruprecht-Karls-University of Heidelberg

Alfred-Weber-Institute for Economics

Grabengasse 14

Germany - 69117 Heidelberg

thushyanthan.baskaran@awi.uni-

heidelberg.de
Lars $P$. Feld

Ruprecht-Karls-University of Heidelberg Alfred-Weber-Institute

Chair of Public Economics

Bergheimerstrasse 58

Germany - 69115 Heidelberg

lars.feld@awi.uni-heidelberg.de

Revised Version, July 2009. - The authors would like to thank conference and seminar participants at Berlin, Bonn, Durham, Freiburg, Garmisch-Partenkirchen, Helsinki, Innsbruck, Kiel, Marburg and Trier, and in particular Helge Berger, Bruno S. Frey, Jürgen von Hagen, Andreas Haufler, Gebhard Kirchgässner and Viktor Steiner for their valuable comments and suggestions. We would also like to acknowledge a grant from the German Science Foundation (DFG SPP 1142). 


\section{Introduction}

Scholars of fiscal federalism are increasingly interested in the relationship between fiscal decentralization and economic growth, and a large number of theoretical and empirical studies have been conducted on this question in recent years. According to the theory of fiscal federalism, fiscal competition leads to efficient allocative outcomes (Oates 1972, Tiebout 1956), which might eventually promote higher rates of economic growth. In addition, the case for decentralization is made on the grounds that localized experimentation leads to more policy innovations (i.e. laboratory federalism, Oates 1999), and that jurisdictional competition forces politicians to provide an efficient bundle of public goods, while limiting their ability to over-tax citizens (Oates 1993, Brennan and Buchanan 1980).

Formal theoretical models also provide arguments for a relationship between decentralization and growth, but the direction of the effect is less clear-cut. While Brueckner (1999) shows that the impact of decentralization on growth depends on the different demand for public goods by the young and the old, Brueckner (2006) finds that decentralization generates incentives to invest in human capital while being young, and, through this channel, increases economic growth permanently. Davoodi and Zou (1998) argue that an efficient level of decentralization exists, and that, if the prevailing level differs from the optimal level, appropriate reforms can increase growth. Rauscher (2007) develops an endogenous growth model with Leviathan governments in which fiscal competition due to decentralization leads to a reduced frequency of political innovation and lower economic growth. He assumes, however, that the private capital stock is constant, and that only public capital accumulation drives economic growth. Relaxing these assumptions, Rauscher (2006) obtains the opposite result: Increased mobility of tax bases yields an increased frequency of political innovation and higher economic growth.

Given these competing results in the theoretical literature, it is not surprising that the empirical evidence is also ambiguous. Several studies find a positive relationship between fiscal decentralization and economic growth. These include, inter alia, Akai and Sakata (2002) who use state-level cross-section data from the US; Stansel (2005) who uses data on 314 US metropolitan areas from 1960-1990; Zhang and Zou (2001) who use data on Indian states; Iimi (2005) who uses a panel of 51 developing and developed 
countries from 1971-2001; and Thießen (2003) who uses panel data from 26 OECD countries. Desai, Freinkman, and Goldberg (2005) also find a positive, but nonlinear relationship between an index of regional economic recovery and the tax retention rate for a panel of Russian sub-federal units.

Other studies fail to find any relationship, and some even identify a negative one. To the first set of studies belong Xie, Zou and Davoodi (1999), who conduct a time-series analysis with data on the US federal level; Woller and Phillips (1998), who use a panel of 23 developing countries; and Thornton (2007), who conducts a cross-section analysis with 19 OECD countries. To the set of studies which find a negative relationship belong Davoodi and Zou (1998), who use a panel of 46 developing and developed countries from 1970-1989, Zhang and Zou (1998), who use a panel of 28 Chinese provinces, and Jin and Zou (2005) who use a panel of 30 Chinese provinces.

When conducting an empirical analysis on the consequences of fiscal decentralization, probably the most important methodological problem is to find an accurate measure of the prevailing degree of decentralization in a given country. Most studies assume a budgetary perspective and use measures constructed by taking the ratio of sub-federal revenues and/or spending to total government revenue and/or spending. Especially in cross-country studies, such measures are usually constructed on the basis of the IMF's Government Finance Statistics (GFS) dataset. One well recognized drawback of the GFS measures is that they provide an inaccurate picture of the "true" level of decentralization. As Rodden (2004) notes, they take the expenditures undertaken and the revenue obtained by sub-federal governments at face value. On the expenditure side, they do not indicate whether sub-federal expenditures are largely mandated by central government regulations. If this were the case, the GFS measures might incorrectly suggest a high degree of decentralization, although the autonomy of sub-federal governments over fiscal matters might actually be negligible. On the revenue side, there is a similar problem. While the data might indicate a high level of revenue decentralization because a large share of the consolidated tax revenue of the public sector flows to subfederal governments, their power to autonomously decide on tax rates or bases might be negligible. That is, a large value of the GFS measures for revenue decentralization might not necessarily imply a large amount of de facto autonomy. 
Noting the deficiencies of the GFS decentralization measures, Thornton (2007) uses a measure that supposedly captures the "true" amount of sub-federal autonomy. This measure, originally provided by OECD (1999) (and updated by Blöchliger and King, 2006), is obtained by differentiating sub-federal tax revenue according to the level of autonomy sub-federal governments have over the associated rates and bases, and then calculating the ratios with regard to total government tax receipts. Even though the data used by Thornton (2007) provide a better approximation of the true extent of decentralization than the GFS measures and hence lend his results credibility, they exhibit two drawbacks. First, they are only available as a cross-section dataset and, second, for 19 countries only. This, in turn, implies that the results, which indicate that there is no robust relationship between fiscal decentralization and economic growth, might be distorted due to unobserved heterogeneity and/or small-sample biases.

The aim of this paper, therefore, is to complement Thornton's (2007) study on the impact of fiscal decentralization on economic growth by addressing these problems while simultaneously using a set of decentralization measures which capture the "true" degree of fiscal decentralization. Our decentralization data is provided by Stegarescu (2005) and is based on the OECD (1999) methodology. It is thus a natural extension of the measures used by Thornton (2007), because it is (a) constructed according to the same classification scheme, (b) available for 23 countries, and, most importantly, (c) as a large yearly panel for the time period 1975-2001. This dataset not only allows the application of panel data methods, but also enables us to conduct several robustness tests.

The remainder of this paper is organized as follows. In the next section, we discuss the decentralization variables, the econometric model, and the methodology. In Section 3, we present our results. In Section 4, we summarize and conclude.

\section{Data and Econometric Model}

\subsection{New Data on Revenue Decentralization}

A first important difference of our as compared to previous studies is the use of Stegarescu's (2005) decentralization data. Following the approach suggested by OECD (1999), he presents two different decentralization measures. The first measure, to which we will refer as revenue decentralization 1 , is constructed by summing all sub-federal tax revenue from taxes for which sub-federal governments may determine either rates, 
bases or both, and then dividing the sum by total government tax revenue. ${ }^{1}$ The second measure, which will be referred to as revenue decentralization 2, is constructed by summing all tax revenue from shared taxes for which sub-federal governments may codetermine the revenue distribution or other allocation details of the joint taxation system, and then dividing the sum by total government tax revenue.

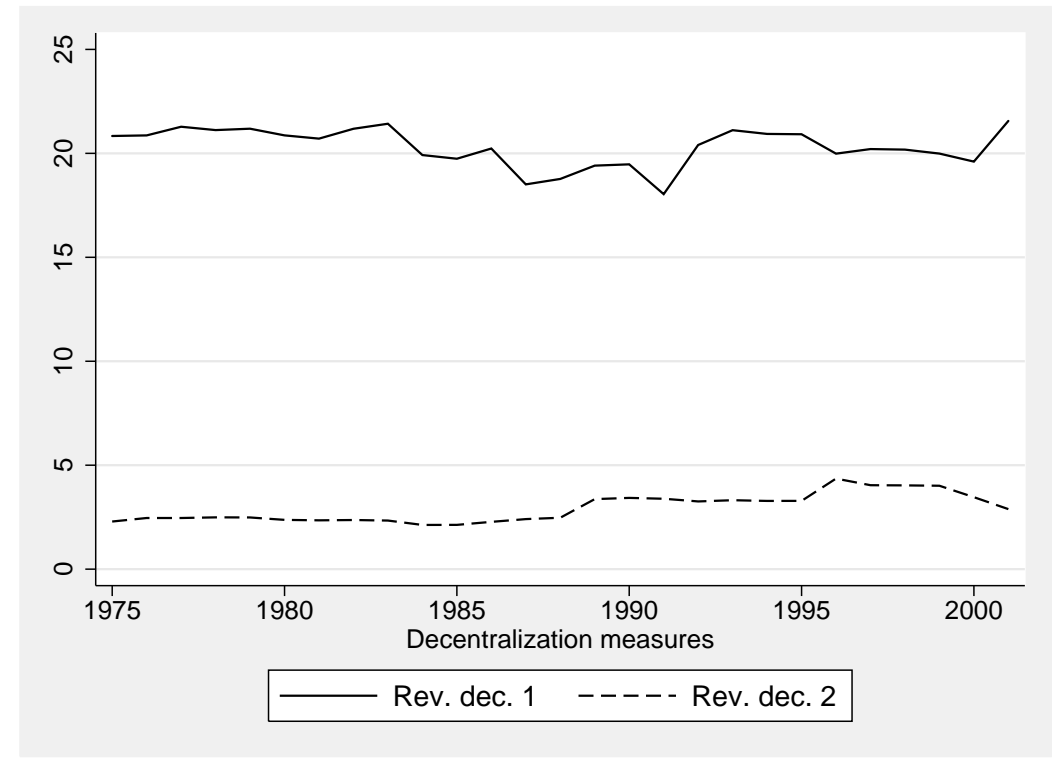

Figure 1: Evolution of the Average of the Decentralization Measures Source: Stegarescu (2005)

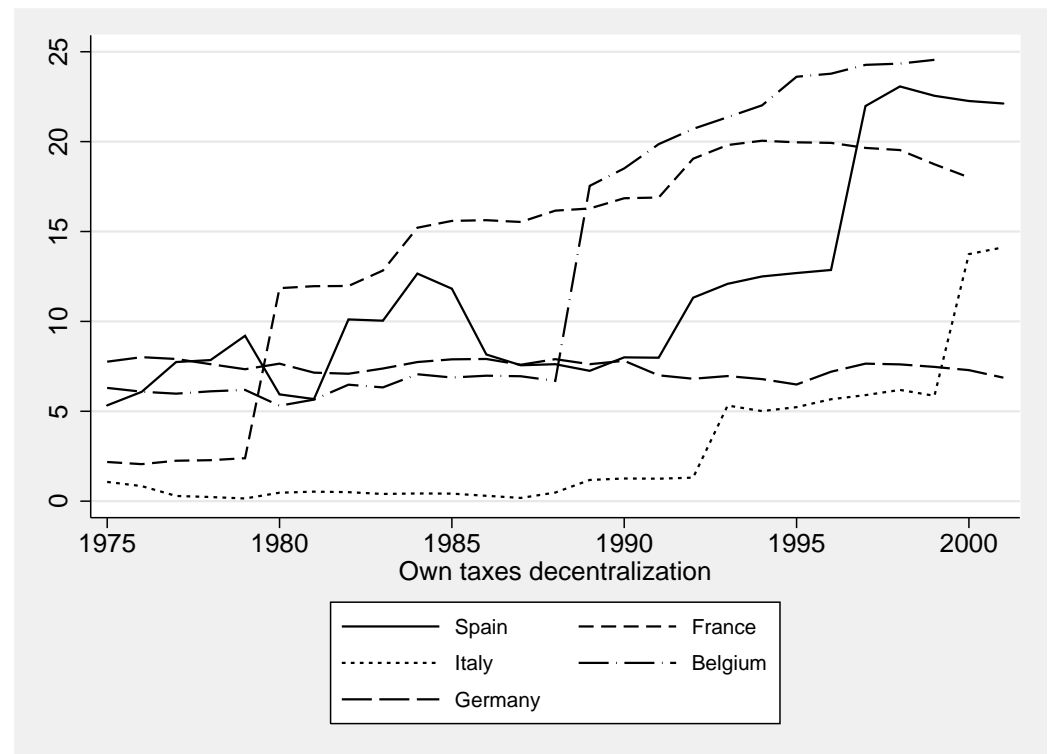

Figure 2: Evolution of Revenue decentralization 1 in Selected Countries Source: Stegarescu (2005)

1. This measure is similar to the one used by Thornton (2007), but also varies across time. 


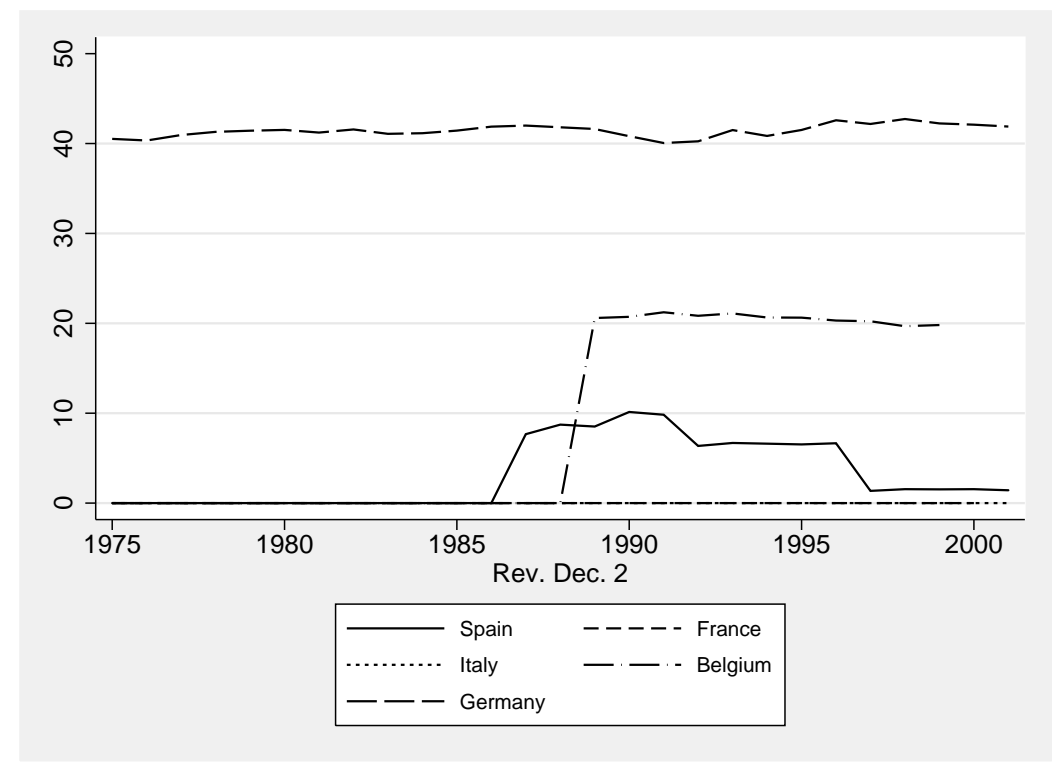

Figure 3: Evolution of Revenue decentralization 2 in Selected Countries Source: Stegarescu (2005)

Figure 1 presents the evolution of the average values of these two measures across time. Apparently, about $20 \%$ of sub-federal revenues originate from taxes over which lower level governments have a large degree of autonomy. In contrast, sub-federal governments have only marginal control over the allocation of shared taxes. Both variables seem to vary little across time, although we observe a slight increase in both decentralization measures since the end of the 1980s.

Figure 2 shows, however, that some countries exhibit a considerable amount of within variation for the revenue decentralization 1 measure. Since the middle of the 1970s, Spain exhibits an increasing trend in tax autonomy. Belgium and Italy have sharp increases in tax autonomy in the end of the 1980s and the beginning of the 1990s, respectively. In France, a modest increase of revenue decentralization can be observed since the process of decentralization started in 1982 (Loi Deferre). Germany, on the other end of the scale, has only little time variation in the revenue decentralization 1 variable.

In Figure 3, we present the evolution of the revenue decentralization 2 variable for the same set of countries. Apparently, there is less within-variation in this variable than in 
the revenue decentralization 1 variable: Only Belgium and Spain display significant changes.

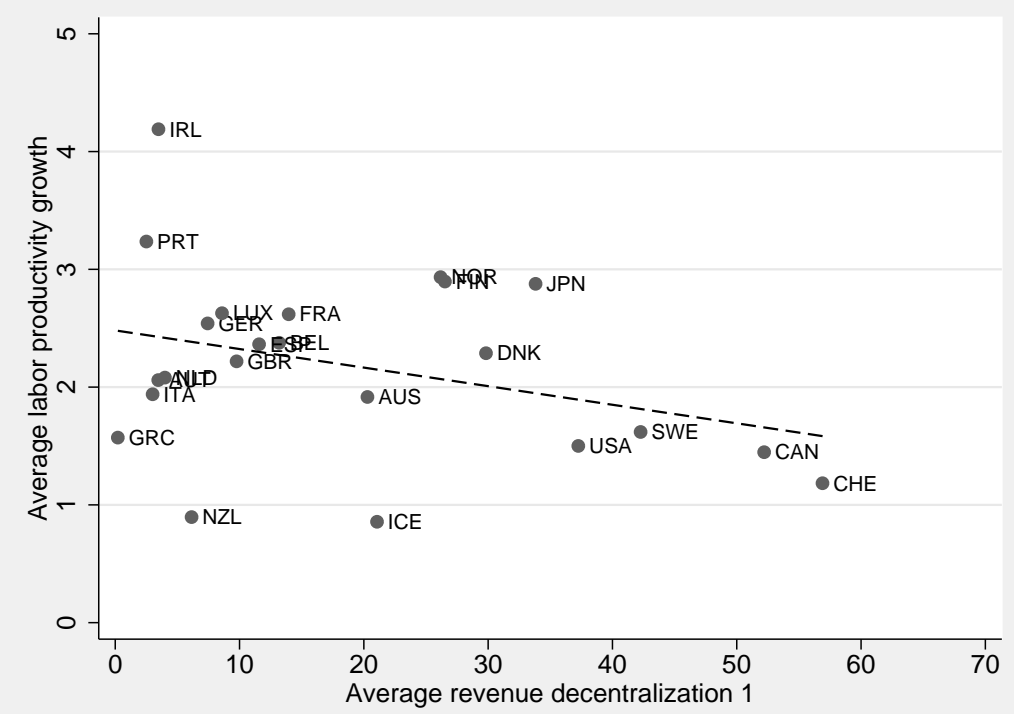

Figure 4: Correlation between Revenue Decentralization 1 and Economic Growth

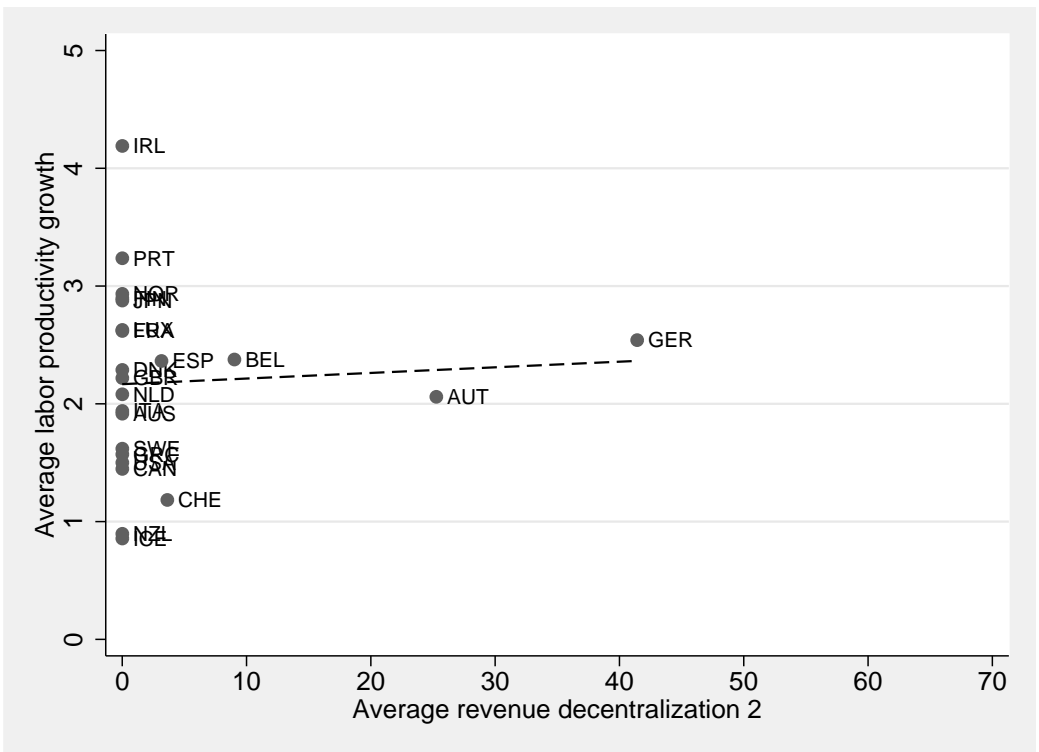

Figure 5: Correlation between Revenue Decentralization 2 and Economic Growth 
In Figure 4, we plot the average level of the revenue decentralization 1 variable in each country against average economic growth for the sample period. This figure indicates that there is substantial between-variation in both the level of economic growth and revenue decentralization between the countries that are considered in this paper. In Figure 5, we plot the average level of the revenue decentralization 2 variable against average labor productivity growth. As evidenced by the previous figures, there are only five countries, Austria, Belgium, Germany, Spain, and Switzerland, with non-zero values for this measure of decentralization.

The bivariate plots indicate (i) a negative relationship between revenue decentralization 1 and labor productivity growth and (ii) a positive but weak relationship between revenue decentralization 2 and labor productivity growth. It remains to be seen, however, whether this association survives more rigorous econometric tests.

\subsection{Econometric Model and Methodology}

Most empirical studies on the relation between decentralization and economic growth propose an econometric framework similar to the approach chosen by Davoodi and Zou (1998). They derive the empirical specification from an endogenous growth model which insinuates that for a given government size, fiscal decentralization has a permanent effect on economic growth. Our econometric model is thus specified as follows:

$$
\text { Economic Growth }_{i t}=\beta_{0}+\beta_{1} \text { Decentralization }_{i t}+\beta_{2} \text { Economic Controls }_{i t}+u_{i t}
$$

The dependent variable in this model is the growth rate of labor productivity. ${ }^{2} \mathrm{We}$ include, in addition to the revenue decentralization measures, several independent variables at the right hand side of equation 1 . In order to control for catch-up effects, the lag of GDP per worker enters the model (note that unlike in cross-section studies, we cannot include the "initial" level of GDP per worker since this variable would be multicollinear with country fixed effects). ${ }^{3}$ We control for the effect of the tax burden (and thus for the size of government) on economic growth by including the tax to GDP ra-

2. Data source: OECD Labor Productivity Growth Dataset.

3. Data source: Penn World Tables 6.2. 
tio. ${ }^{4}$ Human capital is proxied by the gross enrolment rate in secondary education ${ }^{5}$, and the growth rate of physical capital by the investment share from GDP. ${ }^{6}$ We also control for population growth ${ }^{7}$. Additional controls, used for robustness checks, are a measure of integration into the world economy (openness) ${ }^{8}$, the inflation rate ${ }^{9}$, and a federation dummy. ${ }^{10}$ Summary statistics for these unbalanced panel data are provided in Table $1 .{ }^{11}$

Table 1: Summary Statistics

\begin{tabular}{lcrrrr}
\hline Variable & Obs & Mean & Std. Dev. & Min & Max \\
\hline Rev. Dec. 1 & 554 & 20.261 & 16.557 & 0.050 & 61.500 \\
Rev. Dec. 2 & 554 & 2.972 & 9.533 & 0.000 & 42.730 \\
Labor productivity & 554 & 2.181 & 1.946 & -8.700 & 10.000 \\
Investment share & 554 & 24.847 & 4.358 & 15.550 & 42.170 \\
Tax/GDP & 554 & 36.274 & 7.297 & 18.200 & 53.900 \\
Education & 554 & 98.217 & 17.211 & 57.291 & 159.499 \\
Population growth & 554 & 0.006 & 0.004 & -0.003 & 0.016 \\
Lag GDP per worker & 554 & 41.655 & 10.517 & 22.125 & 114.449 \\
Openness & 554 & 60.061 & 41.770 & 10.780 & 286.480 \\
Inflation & 554 & 6.404 & 7.382 & -1.600 & 84.300 \\
Federation & 554 & 0.285 & 0.452 & 0.000 & 1.000 \\
\hline
\end{tabular}

Our test strategy is as follows: In a first step, we conduct the econometric analysis with yearly panel data. In the baseline specifications, we use, individually and jointly, both decentralization variables, the one concerned with tax autonomy and the one concerned with co-decision making. We first estimate the model with pooled OLS. Thereafter, we take the panel characteristics of the dataset into account and estimate random and fixed effects models. The baseline models contains as control variables the tax revenue share of GDP, the investment share, education, population growth, and lagged GDP per worker. As a first robustness checks, we estimate models which additionally include openness, inflation, and the federation dummy. In all models, wee include time-fixed

4. Data source: OECD Revenue Statistics.

5. Data source: World Bank Edstat Database. Data before 1990 is only available in 5-year intervals. We replace the missing observations with the value of the initial year of the period.

6. Data source: Penn World Tables 6.2.

7. Data Source: Penn World Tables 6.2.

8. Data source: Penn World Tables 6.2.

9. Data source: IMF World Economic Outlook.

10. The federation dummy changes its value for Belgium and Spain in the sample period from 0 to 1 (these countries eventually become federations). Since there is some within-variation in this variable, we can include it in the fixed effects regressions. The reader should be aware, though, that any conclusion on the impact of "being a federation" that relies on the results of this set of models is based on the information from only two countries.

11. Note that for Germany before 1991 only data for the western part is available. - The panel is unbalanced mainly due to some lacking observations for Austria, Greece and Portugal. 
effects in order to capture common shocks in the OECD countries in our sample (the estimated coefficients on the time fixed effects are not reported in the regression tables, however). We also use robust standard errors and, when appropriate, cluster observations by countries in order to account for intra-group correlation.

In a second step, we control for "short-term" variability in our variables by estimating regressions on the mean and in five-year averages. In a third step, we acknowledge that both revenue decentralization measures display relatively little time variance (see Figure 1) by estimating fixed effects models without the decentralization and federalism variables as a first stage regression. In a second stage regression, we use the decentralization measures to explain the predicted fixed effects from the first stage by using a method proposed by Hsiao (2003, p. 51-53) and Plümper and Troeger (2007).

\section{Results}

\subsection{Results from Yearly Panel Data}

We start by presenting the results obtained by pooled OLS, random effects, and fixed effects estimations of the baseline model in Table 2. First, note that the economic controls perform reasonably well. The coefficient on the investment share variable is significantly positive in all specifications, albeit insignificant in the random and fixed effects models. Education has an expected positive sign, but is insignificant. Population growth is insignificant. The sign of the coefficient is negative in the models that exploit both the between and within variation (pooled OLS and RE), and positive in the fixed effects models. The lagged GDP per worker has an expected negative sign, which is significant in the random and fixed effects models. The tax share variable is negatively related to growth, a conclusion which especially holds for the fixed effects models where the coefficient becomes significant.

The revenue decentralization 1 variable generally enters with a negative and significant sign in the pooled OLS and the random effects specifications. While it continues to be significant in the first fixed effects model, the coefficient becomes insignificant when both decentralization variables are jointly included. Although the revenue decentralization 2 variable also generally displays a negative sign, it is consistently insignificant. 
Overall, this first set of regressions indicates that sub-federal tax autonomy leads to lower economic growth. It remains to be seen, however, whether this result is robust to alternative specifications of the baseline model.

A first set of such robustness checks are presented in Table 3. In this table, we collect the results from re-estimating the models in Table 2 after including three additional variables: Openness, inflation, and a federation dummy. In general, the economic controls already included in Table 2 display similar coefficients, both in sign and magnitude, as in Table 2. The additionally included control variables also perform reasonably well. Openness enters with a significantly positive coefficient in the pooled OLS and the random effects models, but loses its significance in the fixed effects specifications. Inflation, on the other hand, is significantly negative in the fixed effects models. The coefficient on the federation dummy is consistently negative and significant, a result that is driven by the developments in Spain and Belgium.

The implication of the results for the remaining control variables, which are remarkably similar between Tables 2 and 3, is straightforward. The significantly negative sign of the lagged GDP per worker variable indicates that countries with low levels of productivity tend to have higher growth rates (a catching-up effect). The significantly negative coefficient of the tax to GDP and the inflation variable indicates that both large tax burdens and monetary expansion retard economic growth. The significantly positive coefficient on the openness variable indicates that more open economies tend to grow faster.

The revenue decentralization 1 variable, while continuing to display a negative coefficient, is generally insignificant (except in the first OLS model). Revenue decentralization 2, on the other hand, displays, in contrast to the results in Table 3, a positive coefficient. However, the estimated coefficient is generally insignificant except in the second RE model.

Overall, these results lead to a re-evaluation of the findings from Table 2 with respect to the decentralization variables. Apparently, once additional control variables are taken into account, the finding of a negative relationship between the revenue decentralization variables and economic growth ceases to be valid. We rather find that fiscal decentralization and economic growth are unrelated. 
Table 2: Regressions of Economic Growth on Fiscal Decentralization and Controls, Baseline Specification, 23 OECD Countries, 1975-2001, Unbalanced Panel

\begin{tabular}{|c|c|c|c|c|c|c|c|c|c|}
\hline & $\begin{array}{l}\text { OLS1 } \\
\mathrm{b} / \mathrm{se}\end{array}$ & $\begin{array}{l}\text { OLS2 } \\
\mathrm{b} / \mathrm{se}\end{array}$ & $\begin{array}{l}\text { OLS3 } \\
\mathrm{b} / \mathrm{se}\end{array}$ & $\begin{array}{l}\text { RE1 } \\
\text { b/se }\end{array}$ & $\begin{array}{l}\text { RE2 } \\
\mathrm{b} / \mathrm{se}\end{array}$ & $\begin{array}{l}\text { RE3 } \\
\mathrm{b} / \mathrm{se}\end{array}$ & $\begin{array}{l}\text { FE1 } \\
\text { b/se }\end{array}$ & $\begin{array}{l}\text { FE2 } \\
\text { b/se }\end{array}$ & $\begin{array}{l}\text { FE3 } \\
\text { b/se }\end{array}$ \\
\hline Investment share & $\begin{array}{l}0.072 * * * \\
(0.025)\end{array}$ & $\begin{array}{l}0.052^{*} \\
(0.028)\end{array}$ & $\begin{array}{l}0.075^{* * *} \\
(0.024)\end{array}$ & $\begin{array}{l}0.036 \\
(0.032)\end{array}$ & $\begin{array}{l}0.027 \\
(0.033)\end{array}$ & $\begin{array}{l}0.037 \\
(0.032)\end{array}$ & $\begin{array}{l}0.006 \\
(0.029)\end{array}$ & $\begin{array}{l}0.009 \\
(0.029)\end{array}$ & $\begin{array}{l}0.009 \\
(0.029)\end{array}$ \\
\hline Secondary Education & $\begin{array}{l}0.008 \\
(0.009)\end{array}$ & $\begin{array}{l}0.001 \\
(0.009)\end{array}$ & $\begin{array}{l}0.009 \\
(0.009)\end{array}$ & $\begin{array}{l}0.006 \\
(0.008)\end{array}$ & $\begin{array}{l}0.003 \\
(0.008)\end{array}$ & $\begin{array}{l}0.006 \\
(0.008)\end{array}$ & $\begin{array}{l}0.005 \\
(0.007)\end{array}$ & $\begin{array}{l}0.005 \\
(0.008)\end{array}$ & $\begin{array}{l}0.006 \\
(0.008)\end{array}$ \\
\hline Population growth & $\begin{array}{l}-26.579 \\
(28.432)\end{array}$ & $\begin{array}{l}-36.015 \\
(36.493)\end{array}$ & $\begin{array}{l}-33.138 \\
(28.255)\end{array}$ & $\begin{array}{l}-7.418 \\
(27.790)\end{array}$ & $\begin{array}{l}-9.365 \\
(31.911)\end{array}$ & $\begin{array}{l}-10.107 \\
(28.944)\end{array}$ & $\begin{array}{l}14.181 \\
(34.607)\end{array}$ & $\begin{array}{l}13.964 \\
(34.647)\end{array}$ & $\begin{array}{l}13.469 \\
(34.622)\end{array}$ \\
\hline Lag GDP per worker & $\begin{array}{l}-0.017 \\
(0.012)\end{array}$ & $\begin{array}{l}-0.022 \\
(0.018)\end{array}$ & $\begin{array}{l}-0.016 \\
(0.012)\end{array}$ & $\begin{array}{l}-0.044 * * * \\
(0.013)\end{array}$ & $\begin{array}{l}-0.050 * * * \\
(0.016)\end{array}$ & $\begin{array}{l}-0.045^{* * *} \\
(0.013)\end{array}$ & $\begin{array}{l}-0.117 * * * \\
(0.025)\end{array}$ & $\begin{array}{l}-0.114 * * * \\
(0.025)\end{array}$ & $\begin{array}{l}-0.116^{* * *} \\
(0.025)\end{array}$ \\
\hline Tax/GDP & $\begin{array}{l}0.003 \\
(0.013)\end{array}$ & $\begin{array}{l}0.006 \\
(0.023)\end{array}$ & $\begin{array}{l}0.001 \\
(0.013)\end{array}$ & $\begin{array}{l}-0.017 \\
(0.020)\end{array}$ & $\begin{array}{l}-0.023 \\
(0.025)\end{array}$ & $\begin{array}{l}-0.020 \\
(0.021)\end{array}$ & $\begin{array}{l}-0.107 * * * \\
(0.035)\end{array}$ & $\begin{array}{l}-0.117 * * * \\
(0.035)\end{array}$ & $\begin{array}{l}-0.109^{* * *} \\
(0.035)\end{array}$ \\
\hline Rev. decentralization 1 & $\begin{array}{l}-0.022 * * \\
(0.008)\end{array}$ & - & $\begin{array}{l}-0.023 * * \\
(0.008)\end{array}$ & $\begin{array}{l}-0.022 * * * \\
(0.008)\end{array}$ & - & $\begin{array}{l}-0.022 * * * \\
(0.008)\end{array}$ & $\begin{array}{l}-0.038^{*} \\
(0.021)\end{array}$ & - & $\begin{array}{l}-0.030 \\
(0.023)\end{array}$ \\
\hline Rev. decentralization 2 & - & $\begin{array}{l}-0.002 \\
(0.006)\end{array}$ & $\begin{array}{l}-0.009 \\
(0.007)\end{array}$ & - & $\begin{array}{l}-0.009 \\
(0.011)\end{array}$ & $\begin{array}{l}-0.012 \\
(0.010)\end{array}$ & - & $\begin{array}{l}-0.044 \\
(0.029)\end{array}$ & $\begin{array}{l}-0.027 \\
(0.031)\end{array}$ \\
\hline $\mathrm{N}$ & 554 & 554 & 554 & 554 & 554 & 554 & 554 & 554 & 554 \\
\hline $\bar{R}^{2}$ & 0.082 & 0.052 & 0.082 & - & - & - & 0.103 & 0.102 & 0.102 \\
\hline$\chi^{2}$ & - & - & - & 365.464 & 329.959 & 341.804 & - & - & - \\
\hline $\mathrm{F}$ & - & - & - & - & - & - & 3.801 & 3.619 & 3.678 \\
\hline Root MSE & 1.864 & 1.895 & 1.864 & 1.754 & 1.753 & 1.751 & 1.688 & 1.689 & 1.689 \\
\hline
\end{tabular}

Notes: The numbers in parentheses are the standard errors of the estimated parameters. '*', '**', or '***' denote significance at the 10,5 , or 1 percent level, respectively. $\bar{R}^{2}$ is the adjusted coefficient of determination (corrected by the degrees of freedom). The $\mathrm{F}$ and $\chi^{2}-$ statistics are used to test the significance of the model. The computations have been performed by Stata 9.2. The panel is unbalanced mainly due to some lacking observations for Austria, Greece and Portugal. 
Table 3: Regressions of Economic Growth on Fiscal Decentralization and Controls, Robust Specifications, 23 OECD Countries, 1975-2001, Unbalanced Panel

\begin{tabular}{|c|c|c|c|c|c|c|c|c|c|}
\hline & $\begin{array}{l}\text { OLS1 } \\
\mathrm{b} / \mathrm{se}\end{array}$ & $\begin{array}{l}\text { OLS2 } \\
\mathrm{b} / \mathrm{se}\end{array}$ & $\begin{array}{l}\text { OLS3 } \\
\mathrm{b} / \mathrm{se}\end{array}$ & $\begin{array}{l}\text { RE1 } \\
\text { b/se }\end{array}$ & $\begin{array}{l}\text { RE2 } \\
\mathrm{b} / \mathrm{se}\end{array}$ & $\begin{array}{l}\text { RE3 } \\
\text { b/se }\end{array}$ & $\begin{array}{l}\text { FE1 } \\
\text { b/se }\end{array}$ & $\begin{array}{l}\text { FE2 } \\
\text { b/se }\end{array}$ & $\begin{array}{l}\text { FE3 } \\
\text { b/se }\end{array}$ \\
\hline Investment share & $\begin{array}{l}0.059 * * \\
(0.026)\end{array}$ & $\begin{array}{l}0.040 \\
(0.029)\end{array}$ & $\begin{array}{l}0.056^{*} \\
(0.031)\end{array}$ & $\begin{array}{l}0.041 \\
(0.029)\end{array}$ & $\begin{array}{l}0.035 \\
(0.029)\end{array}$ & $\begin{array}{l}0.037 \\
(0.030)\end{array}$ & $\begin{array}{l}0.027 \\
(0.029)\end{array}$ & $\begin{array}{l}0.028 \\
(0.029)\end{array}$ & $\begin{array}{l}0.027 \\
(0.029)\end{array}$ \\
\hline Population growth & $\begin{array}{l}-17.630 \\
(23.986)\end{array}$ & $\begin{array}{l}-9.301 \\
(32.193)\end{array}$ & $\begin{array}{l}-13.576 \\
(29.703)\end{array}$ & $\begin{array}{l}-4.593 \\
(23.068)\end{array}$ & $\begin{array}{l}-0.005 \\
(24.077)\end{array}$ & $\begin{array}{l}0.301 \\
(24.577)\end{array}$ & $\begin{array}{l}10.852 \\
(34.870)\end{array}$ & $\begin{array}{l}10.483 \\
(34.867)\end{array}$ & $\begin{array}{l}10.808 \\
(34.914)\end{array}$ \\
\hline Tax/GDP & $\begin{array}{l}-0.030 \\
(0.021)\end{array}$ & $\begin{array}{l}-0.040^{*} \\
(0.023)\end{array}$ & $\begin{array}{l}-0.032 \\
(0.023)\end{array}$ & $\begin{array}{l}-0.063 * * * \\
(0.022)\end{array}$ & $\begin{array}{l}-0.068 * * * \\
(0.022)\end{array}$ & $\begin{array}{l}-0.068^{* * * *} \\
(0.023)\end{array}$ & $\begin{array}{l}-0.117 * * * \\
(0.037)\end{array}$ & $\begin{array}{l}-0.120 * * * \\
(0.037)\end{array}$ & $\begin{array}{l}-0.116^{* * *} \\
(0.037)\end{array}$ \\
\hline Openness & $\begin{array}{l}0.010^{*} \\
(0.005)\end{array}$ & $\begin{array}{l}0.011 * * \\
(0.005)\end{array}$ & $\begin{array}{l}0.010^{*} \\
(0.005)\end{array}$ & $\begin{array}{l}0.016^{* * *} \\
(0.005)\end{array}$ & $\begin{array}{l}0.016^{* * * *} \\
(0.005)\end{array}$ & $\begin{array}{l}0.016^{* * * *} \\
(0.005)\end{array}$ & $\begin{array}{l}0.016^{*} \\
(0.009)\end{array}$ & $\begin{array}{l}0.016^{*} \\
(0.009)\end{array}$ & $\begin{array}{l}0.016^{*} \\
(0.009)\end{array}$ \\
\hline Inflation & $\begin{array}{l}-0.068^{* * *} \\
(0.011)\end{array}$ & $\begin{array}{l}-0.068^{* * * *} \\
(0.010)\end{array}$ & $\begin{array}{l}-0.068^{* * * *} \\
(0.011)\end{array}$ & $\begin{array}{l}-0.053^{* * * *} \\
(0.013)\end{array}$ & $\begin{array}{l}-0.052^{* * * *} \\
(0.013)\end{array}$ & $\begin{array}{l}-0.052 * * * \\
(0.013)\end{array}$ & $\begin{array}{l}-0.041 \\
(0.027)\end{array}$ & $\begin{array}{l}-0.041 \\
(0.027)\end{array}$ & $\begin{array}{l}-0.042 \\
(0.027)\end{array}$ \\
\hline Rev. decentralization 2 & & $\begin{array}{l}0.018 \\
(0.012)\end{array}$ & $\begin{array}{l}0.006 \\
(0.014)\end{array}$ & & $\begin{array}{l}0.022 * * \\
(0.010)\end{array}$ & $\begin{array}{l}0.018 \\
(0.013)\end{array}$ & & $\begin{array}{l}0.004 \\
(0.042) \\
\end{array}$ & $\begin{array}{l}0.007 \\
(0.042)\end{array}$ \\
\hline $\mathrm{N}$ & 554 & 554 & 554 & 554 & 554 & 554 & 554 & 554 & 554 \\
\hline $\bar{R}^{2}$ & 0.140 & 0.135 & 0.139 & - & - & - & 0.117 & 0.116 & 0.115 \\
\hline$\chi^{2}$ & - & - & - & 332.941 & 505.839 & 494.371 & - & - & - \\
\hline $\mathrm{F}$ & - & - & - & - & - & - & 3.803 & 3.739 & 3.719 \\
\hline Root MSE & 1.804 & 1.809 & 1.806 & 1.711 & 1.710 & 1.710 & 1.675 & 1.676 & 1.677 \\
\hline
\end{tabular}

For Notes: See Table 2 


\subsection{Controlling for short-term variability}

In this section, we further explore whether fiscal decentralization in indeed insignificant, or whether the results in the previous sections are a consequence of certain characteristics of the data or incorrectly specified models. In particular, the results might be biased because of short-term variability in both the dependent and some of the independent variables. Such variability could cause the estimated coefficients to be dominated by spurious correlations, or the associated standard errors to be inflated.

Table 4: Regressions of Economic Growth on Fiscal Decentralization and Controls, Regressions on the Mean, 23 OECD Countries, 1975-2001, Unbalanced Panel

\begin{tabular}{|c|c|c|c|c|c|}
\hline & $\begin{array}{l}\text { OLS1 } \\
\mathrm{b} / \mathrm{se}\end{array}$ & $\begin{array}{l}\text { OLS2 } \\
\mathrm{b} / \mathrm{se}\end{array}$ & $\begin{array}{l}\text { OLS3 } \\
\mathrm{b} / \mathrm{se}\end{array}$ & $\begin{array}{l}\text { OLS4 } \\
\mathrm{b} / \mathrm{se}\end{array}$ & $\begin{array}{l}\text { OLS5 } \\
\mathrm{b} / \mathrm{se}\end{array}$ \\
\hline Investment share & $\begin{array}{l}0.103 * * * \\
(0.027)\end{array}$ & $\begin{array}{l}0.067 * * \\
(0.030)\end{array}$ & $\begin{array}{l}0.083^{*} \\
(0.044)\end{array}$ & $\begin{array}{l}0.056 \\
(0.043)\end{array}$ & $\begin{array}{l}0.075 \\
(0.053)\end{array}$ \\
\hline Secondary Education & $\begin{array}{l}0.015 \\
(0.023)\end{array}$ & $\begin{array}{l}-0.006 \\
(0.024)\end{array}$ & $\begin{array}{l}-0.002 \\
(0.021)\end{array}$ & $\begin{array}{l}-0.015 \\
(0.023)\end{array}$ & $\begin{array}{l}0.007 \\
(0.029)\end{array}$ \\
\hline Population growth & $\begin{array}{l}-35.442 \\
(56.674)\end{array}$ & $\begin{array}{l}-60.810 \\
(71.302)\end{array}$ & $\begin{array}{l}-5.543 \\
(58.376)\end{array}$ & $\begin{array}{l}-36.686 \\
(76.252)\end{array}$ & $\begin{array}{l}-21.262 \\
(62.964)\end{array}$ \\
\hline Lag GDP per worker & $\begin{array}{l}-0.004 \\
(0.018)\end{array}$ & $\begin{array}{l}-0.008 \\
(0.024)\end{array}$ & $\begin{array}{l}-0.049 \\
(0.033)\end{array}$ & $\begin{array}{l}-0.059 \\
(0.039)\end{array}$ & $\begin{array}{l}-0.038 \\
(0.032)\end{array}$ \\
\hline Tax/GDP & $\begin{array}{l}0.003 \\
(0.023)\end{array}$ & $\begin{array}{l}0.014 \\
(0.041)\end{array}$ & $\begin{array}{l}0.001 \\
(0.035)\end{array}$ & $\begin{array}{l}-0.001 \\
(0.052)\end{array}$ & $\begin{array}{l}-0.014 \\
(0.044)\end{array}$ \\
\hline Openness & - & - & $\begin{array}{l}0.008 \\
(0.007)\end{array}$ & $\begin{array}{l}0.012 \\
(0.007)\end{array}$ & $\begin{array}{l}0.007 \\
(0.007)\end{array}$ \\
\hline Inflation & - & - & $\begin{array}{l}-0.090 * * * \\
(0.030)\end{array}$ & $\begin{array}{l}-0.089 * * \\
(0.034)\end{array}$ & $\begin{array}{l}-0.098 * * \\
(0.037)\end{array}$ \\
\hline Federation dummy & - & - & - & - & $\begin{array}{l}-0.215 \\
(0.470)\end{array}$ \\
\hline Rev. decentralization 1 & $\begin{array}{l}-0.023 * \\
(0.011)\end{array}$ & - & $\begin{array}{l}-0.018 \\
(0.011)\end{array}$ & - & $\begin{array}{l}-0.019 \\
(0.011)\end{array}$ \\
\hline Rev. decentralization 2 & - & $\begin{array}{l}-0.005 \\
(0.010) \\
\end{array}$ & - & $\begin{array}{l}-0.007 \\
(0.010) \\
\end{array}$ & $\begin{array}{l}-0.009 \\
(0.016) \\
\end{array}$ \\
\hline $\mathrm{N}$ & 23 & 23 & 23 & 23 & 23 \\
\hline $\bar{R}^{2}$ & 0.083 & 0.146 & 0.235 & 0.110 & 0.168 \\
\hline $\mathrm{F}$ & 4.639 & 2.004 & 8.108 & 6.567 & 13.083 \\
\hline Root MSE & 0.752 & 0.840 & 0.687 & 0.741 & 0.716 \\
\hline
\end{tabular}

For Notes: See Table 2.

To investigate this possibility, we conduct regressions on the mean. That is, we calculate the country averages of the dependent and independent variables of the fully specified model in Table 3, and then estimate a purely cross-sectional model. This approach has the advantage that it underlines the long-run growth effects of the included factors. In particular, the relatively larger within variation of fiscal decentralization is exploited. Compared to a cross-section analysis for one single year, averaging in the regressions 
on the mean avoids the reliance on the idiosyncracies of that singular year. However, the results, which are presented in Table 4, continue to suggest that sub-federal autonomy is not significantly affecting economic growth: both decentralization measures are insignificant once they are jointly included.

A shortcoming of the regression on the mean approach is that it completely discards the panel characteristics of the data. Therefore, using five-year instead of full cross-section averages might be a reasonable compromise between taking the within-variation in the panel into account and controlling for short-term variability.

Table 5: Regressions of Economic Growth on Fiscal Decentralization and Controls, Five Year Averages, 23 OECD Countries, 1975-2001

\begin{tabular}{|c|c|c|c|c|c|c|}
\hline & $\begin{array}{l}\text { OLS } \\
\mathrm{b} / \mathrm{se}\end{array}$ & $\begin{array}{l}\mathrm{RE} \\
\mathrm{b} / \mathrm{se}\end{array}$ & $\begin{array}{l}\mathrm{FE} \\
\mathrm{b} / \mathrm{se}\end{array}$ & $\begin{array}{l}\text { OLS } \\
\mathrm{b} / \mathrm{se}\end{array}$ & $\begin{array}{l}\mathrm{RE} \\
\mathrm{b} / \mathrm{se}\end{array}$ & $\begin{array}{l}\text { FE } \\
b / s e\end{array}$ \\
\hline Investment share & $\begin{array}{l}0.100 * * * \\
(0.027)\end{array}$ & $\begin{array}{l}0.092 * * * \\
(0.031)\end{array}$ & $\begin{array}{l}0.032 \\
(0.056)\end{array}$ & $\begin{array}{l}0.071 * \\
(0.036)\end{array}$ & $\begin{array}{l}0.069^{*} \\
(0.037)\end{array}$ & $\begin{array}{l}0.052 \\
(0.063)\end{array}$ \\
\hline Education & $\begin{array}{l}-0.003 \\
(0.012)\end{array}$ & $\begin{array}{l}-0.002 \\
(0.011)\end{array}$ & $\begin{array}{l}-0.002 \\
(0.012)\end{array}$ & $\begin{array}{l}-0.004 \\
(0.010)\end{array}$ & $\begin{array}{l}-0.005 \\
(0.010)\end{array}$ & $\begin{array}{l}-0.003 \\
(0.013)\end{array}$ \\
\hline Population growth & $\begin{array}{l}-21.314 \\
(30.991)\end{array}$ & $\begin{array}{l}-19.662 \\
(34.926)\end{array}$ & $\begin{array}{l}-8.486 \\
(45.236)\end{array}$ & $\begin{array}{l}-13.356 \\
(32.604)\end{array}$ & $\begin{array}{l}-13.056 \\
(35.934)\end{array}$ & $\begin{array}{l}-15.823 \\
(47.134)\end{array}$ \\
\hline Lag GDP per worker & $\begin{array}{l}-0.000 \\
(0.000)\end{array}$ & $\begin{array}{l}-0.000 * * \\
(0.000)\end{array}$ & $\begin{array}{l}-0.000 * * * \\
(0.000)\end{array}$ & $\begin{array}{l}-0.000 * * \\
(0.000)\end{array}$ & $\begin{array}{l}-0.000 * * * \\
(0.000)\end{array}$ & $\begin{array}{l}-0.000 * * * \\
(0.000)\end{array}$ \\
\hline Tax/GDP & $\begin{array}{l}0.019 \\
(0.016)\end{array}$ & $\begin{array}{l}0.015 \\
(0.019)\end{array}$ & $\begin{array}{l}-0.057 \\
(0.050)\end{array}$ & $\begin{array}{l}-0.019 \\
(0.025)\end{array}$ & $\begin{array}{l}-0.024 \\
(0.025)\end{array}$ & $\begin{array}{l}-0.053 \\
(0.000)\end{array}$ \\
\hline Openness & - & - & - & $\begin{array}{l}0.012 * * \\
(0.005)\end{array}$ & $\begin{array}{l}0.013 * * * \\
(0.005)\end{array}$ & $\begin{array}{l}0.010 \\
(0.011)\end{array}$ \\
\hline Inflation & - & - & - & $\begin{array}{l}-0.044 * * \\
(0.018)\end{array}$ & $\begin{array}{l}-0.039 * \\
(0.022)\end{array}$ & $\begin{array}{l}-0.024 \\
(0.036)\end{array}$ \\
\hline Rev. decentralization 1 & $\begin{array}{l}-0.024 * * * \\
(0.008)\end{array}$ & $\begin{array}{l}-0.024 * * * \\
(0.007)\end{array}$ & $\begin{array}{l}-0.029 \\
(0.019)\end{array}$ & $\begin{array}{l}-0.010 \\
(0.007)\end{array}$ & $\begin{array}{l}-0.008 \\
(0.008)\end{array}$ & $\begin{array}{l}-0.025 \\
(0.020)\end{array}$ \\
\hline Rev. decentralization 2 & $\begin{array}{l}-0.009 \\
(0.007)\end{array}$ & $\begin{array}{l}-0.011 \\
(0.009)\end{array}$ & $\begin{array}{l}-0.006 \\
(0.038)\end{array}$ & $\begin{array}{l}0.006 \\
(0.014)\end{array}$ & $\begin{array}{l}0.009 \\
(0.017)\end{array}$ & $\begin{array}{l}0.038 \\
(0.027)\end{array}$ \\
\hline Federation dummy & - & - & - & $\begin{array}{l}-0.457 \\
(0.515)\end{array}$ & $\begin{array}{l}-0.563 \\
(0.586)\end{array}$ & $\begin{array}{l}-1.198 \\
(0.730)\end{array}$ \\
\hline $\mathrm{N}$ & 107 & 107 & 107 & 107 & 107 & 107 \\
\hline $\bar{R}^{2}$ & 0.172 & - & 0.154 & 0.272 & - & 0.157 \\
\hline $\mathrm{F}$ & 7.563 & - & 4.709 & 11.603 & - & 6.766 \\
\hline
\end{tabular}

For Notes: See Table 2.

The results from estimating both the baseline and the fully specified model in which the two decentralization variables are jointly included with five-year averages are collected in Table 5. They confirm the previous results for both the decentralization and the remaining control variables. They indicate in particular that once we control for inflation, openness, and whether a country is a federation, both revenue decentralization 1 and 2 are not robustly related to economic growth. 


\subsection{Explaining the Fixed Effects by Decentralization and Fiscal Federalism}

As argued above, one reason as to why the coefficients of the decentralization variables are insignificant in the fixed effects models might be that the amount of within-variation in these variables is insufficient to obtain precise estimates. Indeed, most of the variation in the decentralization variables, as evidenced by the Figures 1 to 3 , is between countries.

Since revenue arrangements between tiers of government are quite sticky and rarely change, they can be thought of as a part of the long run institutional structure of the state; and since institutional features tend to be relatively constant over time, it might not be surprising that the revenue decentralization variables are insignificant in the fixed effects models. It is well known that if a variable is measured with error and displays a low level of within variation, fixed effects models aggravate the attenuation bias caused by the errors in variables problem. In effect, the estimates are biased towards zero in this case (Johnston and Dinardo, 1997, p. 400).

In order to deal with the problem of low within variation, we apply a procedure proposed by Hsiao (2003, p. 51-53) and Plümper and Troeger (2007). They suggest that a fixed effects model without those variables which exhibit low within-variation should be estimated initially. Then, the predicted fixed effects should be retrieved. Finally, they should be regressed on the average values of the variables with low within variation. The idea is to explain a country's autonomous propensity to grow by its time constant institutional structure.

Table 6: Regression on Fixed Effects, OECD Countries

\begin{tabular}{lllll}
\hline & $\begin{array}{l}\text { OLS1 } \\
\mathrm{b} / \mathrm{se}\end{array}$ & $\begin{array}{l}\text { OLS2 } \\
\mathrm{b} / \mathrm{se}\end{array}$ & $\begin{array}{l}\text { OLS3 } \\
\mathrm{b} / \mathrm{se}\end{array}$ & $\begin{array}{l}\text { OLS4 } \\
\mathrm{b} / \mathrm{se}\end{array}$ \\
\hline Rev. decentralization 1 & -0.009 & & -0.007 & 0.006 \\
& $(0.016)$ & & $\begin{array}{l}(0.018) \\
(0.018)\end{array}$ \\
Rev. decentralization 2 & & 0.021 & $\begin{array}{l}0.018 \\
(0.018)\end{array}$ & $\begin{array}{l}0.050^{* *} \\
(0.023)\end{array}$ \\
Federation dummy & & $(0.015)$ & $\left(0.086^{*}\right.$ \\
& & & & $-1.579)$ \\
\hline $\mathrm{N}$ & 23 & 23 & 23 & 23 \\
$\bar{R}^{2}$ & -0.035 & -0.025 & -0.069 & -0.030 \\
$\mathrm{~F}$ & 0.346 & 1.947 & 1.264 & 2.430 \\
Root MSE & 1.424 & 1.417 & 1.448 & 1.421 \\
\hline For Notes: See Table 2 & & & &
\end{tabular}

For Notes: See Table 2. 
We present the results from this procedure in Table 6. Note that the fixed effects are retrieved after estimating a model with the "robust" specification (the one which includes all control variables). The estimation results collected in this table indicate that once it is controlled for whether a country is a federation, both revenue decentralization 1 and 2 are positively related to economic growth, even though only revenue decentralization 2 is significant. Being a federation, on the other hand, seems to lead to lower growth rates as evidenced by the negative and significant coefficient on this dummy variable.

Overall, these results confirm the findings from Table 3. There is no evidence that revenue decentralization leads to lower growth rates. On the contrary, there is even some evidence that sub-federal control over shared taxes is beneficial for economic outcomes. On the other hand, federations seem to have lower growth rates.

\section{Conclusion}

This paper is motivated by the recent results of Thornton (2007) who, by applying a measure of fiscal decentralization which captures the "true" amount of sub-federal autonomy, finds that there is no significant relationship between fiscal decentralization and economic growth. We draw on similar data, but extend his approach by (a) using a panel dataset, (b) a slightly larger number of countries, and (c) more detailed specifications. In initial regressions, we obtain that fiscal decentralization is negatively related to economic growth. However, several robustness checks indicate that this result is not robust. Overall, we find that revenue decentralization is unrelated to economic outcomes. In fact, there is even some evidence that sub-federal control over shared taxes leads to more economic growth.

On the other hand, a high degree of political instead of fiscal autonomy of sub-federal units seems to impede economic growth, as indicated by the consistently negative sign of the federation dummy. These results show that it is important to distinguish between political and fiscal autonomy of lower-level governments when discussing whether decentralization improves or retards economic growth. While political autonomy seems to be harmful because of, for example, the introduction of additional veto players (Tsebelis, 1995), fiscal decentralization seems to be either irrelevant or even favorable for economic outcomes. 


\section{References}

Akai, N. and M. Sakata (2002). Fiscal Decentralization Contributes to Economic Growth: Evidence from State-level Cross Section Data for the United States, Journal of Urban Economics 52, 93-108.

Blöchliger, H. and D. King (2006), Fiscal Autonomy of Sub-Central Governments. Working Paper No. 2, OECD Network on Fiscal Relations across Levels of Government, Paris.

Brennan, G. and J.M. Buchanan (1980). The Power to Tax: Analytical Foundations of a Fiscal Constitution. Cambridge: Cambridge University Press.

Brueckner, J. (1999). Fiscal Federalism and Capital Accumulation. Journal of Public Economic Theory 1, 205-224.

Brueckner, J. (2006). Fiscal Federalism and Economic Growth. Journal of Public Economics 90, 2107-2120.

Davoodi, H. and H. Zou (1998). Fiscal Decentralization and Economic Growth: A Cross-Country Study. Journal of Urban Economics 43, 244-257.

Desai, R.M., L.M. Freinkman and I. Goldberg (2005). Fiscal Federalism in Rentier Regions: Evidence from Russia, Journal of Comparative Economics 33, 814-834.

Hsiao, C. (2003). Analysis of Panel Data. Cambridge: Cambridge University Press.

Iimi, A. (2005). Decentralization and Economic Growth Revisited: An Empirical Note. Journal of Urban Economics 57, 449-461.

Jin, J. and H. Zou (2005). Fiscal Decentralization, Revenue and Expenditure Assignments, and Growth in China. Journal of Asian Economics 16, 1047-1064.

Johnston, J. and J. Dinardo (1997). Econometric Methods. Singapore: McGraw-Hill

Oates, W.E. (1972). Fiscal Federalism. New York: Harcourt Brace Jovanovich.

Oates, W.E. (1993). Fiscal Decentralization and Economic Development. National Tax Journal 46, 237-243.

Oates, W.E. (1999). An Essay on Fiscal Federalism, Journal of Economic Literature 37, $1120-1149$.

OECD (1999). Taxing Power of State and Local Government. OECD Tax Policy Studies, Paris: OECD.

Plümper, T. and V.E. Troeger (2007). Efficient Estimation of Time-Invariant and Rarely Changing Variables in Finite Sample Panel Analyses with Unit Fixed Effects, Political Analysis 15, 124-139.

Rauscher, M. (2006). Interjurisdictional Competition and Innovation in the Public Sector. Unpublished Manuscript, University of Rostock.

Rauscher, M. (2007). Tax Competition, Capital Mobility and Innovation in the Public Sector. German Economic Review 8, 28-40.

Rodden, J. (2004). Comparative Federalism and Decentralization. On Meaning and Measurement. Comparative Politics 36, 481-500.

Stansel, D. (2005). Local Decentralization and Local Economic Growth: A CrossSectional Examination of US Metropolitan Areas. Journal of Urban Economics 57, 55-72. 
Stegarescu, D. (2005). Public Sector Decentralization: Measurement Concepts and Recent International Trends. Fiscal Studies 26, 301-333.

Thiessen, U. (2003). Fiscal Decentralization and Economic Growth in High Income OECD Countries. Fiscal Studies 24, 237-274.

Thornton, J. (2007). Fiscal Decentralization and Economic Growth Reconsidered. Journal of Urban Economics 61, 64-70.

Tiebout, C. (1956). A Pure Theory of Local Expenditures. Journal of Political Economy 64, 416-424.

Tsebelis, G. (1995). Decision Making in Political Systems: Veto Players in Presidentialism, Parliamentarism, Multicameralism and Multipartyism. British Journal of Political Science 25, 289-325.

Woller, G.M. and K. Phillips (1998). Fiscal Decentralization and LDC Economic Growth: An Empirical Investigation. Journal of Development Studies 34, 139148.

Xie, D., H. Zou, and H. Davoodi (1999). Fiscal Decentralization and Economic Growth in the United States. Journal of Urban Economics 45, 228-239.

Zhang, T. and H. Zou (1998). Fiscal Decentralization, Public Spending, and Economic Growth. Journal of Public Economics 67, 221-240.

Zhang, T. and H. Zou (2001). The Growth Impact of Intersectoral and Intergovernmental Allocation of Public Expenditures: With Applications to China and India. China Economic Review 12, 58-81. 


\section{CESifo Working Paper Series}

for full list see www.cesifo-group.org/wp

(address: Poschingerstr. 5, 81679 Munich, Germany, office@cesifo.de)

2657 Susanne Neckermann, Reto Cueni and Bruno S. Frey, What is an Award Worth? An Econometric Assessment of the Impact of Awards on Employee Performance, May 2009

2658 Steven Brakman, Harry Garretsen and Charles van Marrewijk, Economic Geography within and between European Nations: The Role of Market Potential and Density across Space and Time, May 2009

2659 Giovanni Facchini and Cecilia Testa, Reforming Legislatures: Is one House better than two?, May 2009

2660 Carsten Kowalczyk and Raymond Riezman, Trade Agreements, May 2009

2661 Oliver Falck, Stephan Heblich and Elke Luedemann, Identity and Entrepreneurship, May 2009

2662 Christian Lessmann and Gunther Markwardt, One Size Fits All? Decentralization, Corruption, and the Monitoring of Bureaucrats, May 2009

2663 Felix Bierbrauer, On the Legitimacy of Coercion for the Financing of Public Goods, May 2009

2664 Alessandro Cigno, Agency in Family Policy: A Survey, May 2009

2665 Claudia M. Buch and Christian Pierdzioch, Low Skill but High Volatility?, May 2009

2666 Hendrik Jürges, Kerstin Schneider, Martin Senkbeil and Claus H. Carstensen, Assessment Drives Learning: The Effect of Central Exit Exams on Curricular Knowledge and Mathematical Literacy, June 2009

2667 Eric A. Hanushek and Ludger Woessmann, Schooling, Cognitive Skills, and the Latin American Growth Puzzle, June 2009

2668 Ourania Karakosta, Christos Kotsogiannis and Miguel-Angel Lopez-Garcia, Does Indirect Tax Harmonization Deliver Pareto Improvements in the Presence of Global Public Goods?, June 2009

2669 Aleksandra Riedl and Silvia Rocha-Akis, Testing the Tax Competition Theory: How Elastic are National Tax Bases in OECD Countries?, June 2009

2670 Dominique Demougin and Carsten Helm, Incentive Contracts and Efficient Unemployment Benefits, June 2009

2671 Guglielmo Maria Caporale and Luis A. Gil-Alana, Long Memory in US Real Output per Capita, June 2009 
2672 Jim Malley and Ulrich Woitek, Productivity Shocks and Aggregate Cycles in an Estimated Endogenous Growth Model, June 2009

2673 Vivek Ghosal, Business Strategy and Firm Reorganization under Changing Market Conditions, June 2009

2674 Francesco Menoncin and Paolo M. Panteghini, Retrospective Capital Gains Taxation in the Real World, June 2009

2675 Thomas Hemmelgarn and Gaëtan Nicodème, Tax Co-ordination in Europe: Assessing the First Years of the EU-Savings Taxation Directive, June 2009

2676 Oliver Himmler, The Effects of School Competition on Academic Achievement and Grading Standards, June 2009

2677 Rolf Golombek and Michael Hoel, International Cooperation on Climate-Friendly Technologies, June 2009

2678 Martin Cave and Matthew Corkery, Regulation and Barriers to Trade in Telecommunications Services in the European Union, June 2009

2679 Costas Arkolakis, A Unified Theory of Firm Selection and Growth, June 2009

2680 Michelle R. Garfinkel, Stergios Skaperdas and Constantinos Syropoulos, International Trade and Transnational Insecurity: How Comparative Advantage and Power are Jointly Determined, June 2009

2681 Marcelo Resende, Capital Structure and Regulation in U.S. Local Telephony: An Exploratory Econometric Study; June 2009

2682 Marc Gronwald and Janina Ketterer, Evaluating Emission Trading as a Policy Tool Evidence from Conditional Jump Models, June 2009

2683 Stephan O. Hornig, Horst Rottmann and Rüdiger Wapler, Information Asymmetry, Education Signals and the Case of Ethnic and Native Germans, June 2009

2684 Benoit Dostie and Rajshri Jayaraman, The Effect of Adversity on Process Innovations and Managerial Incentives, June 2009

2685 Peter Egger, Christian Keuschnigg and Hannes Winner, Incorporation and Taxation: Theory and Firm-level Evidence, June 2009

2686 Chrysovalantou Milliou and Emmanuel Petrakis, Timing of Technology Adoption and Product Market Competition, June 2009

2687 Hans Degryse, Frank de Jong and Jérémie Lefebvre, An Empirical Analysis of Legal Insider Trading in the Netherlands, June 2009

2688 Subhasish M. Chowdhury, Dan Kovenock and Roman M. Sheremeta, An Experimental Investigation of Colonel Blotto Games, June 2009 
2689 Alexander Chudik, M. Hashem Pesaran and Elisa Tosetti, Weak and Strong Cross Section Dependence and Estimation of Large Panels, June 2009

2690 Mohamed El Hedi Arouri and Christophe Rault, On the Influence of Oil Prices on Stock Markets: Evidence from Panel Analysis in GCC Countries, June 2009

2691 Lars P. Feld and Christoph A. Schaltegger, Political Stability and Fiscal Policy - Time Series Evidence for the Swiss Federal Level since 1849, June 2009

2692 Michael Funke and Marc Gronwald, A Convex Hull Approach to Counterfactual Analysis of Trade Openness and Growth, June 2009

2693 Patricia Funk and Christina Gathmann, Does Direct Democracy Reduce the Size of Government? New Evidence from Historical Data, 1890-2000, June 2009

2694 Kirsten Wandschneider and Nikolaus Wolf, Shooting on a Moving Target: Explaining European Bank Rates during the Interwar Period, June 2009

2695 J. Atsu Amegashie, Third-Party Intervention in Conflicts and the Indirect Samaritan's Dilemma, June 2009

2696 Enrico Spolaore and Romain Wacziarg, War and Relatedness, June 2009

2697 Steven Brakman, Charles van Marrewijk and Arjen van Witteloostuijn, Market Liberalization in the European Natural Gas Market - the Importance of Capacity Constraints and Efficiency Differences, July 2009

2698 Huifang Tian, John Whalley and Yuezhou Cai, Trade Sanctions, Financial Transfers and BRIC's Participation in Global Climate Change Negotiations, July 2009

2699 Axel Dreher and Justina A. V. Fischer, Government Decentralization as a Disincentive for Transnational Terror? An Empirical Analysis, July 2009

2700 Balázs Égert, Tomasz Koźluk and Douglas Sutherland, Infrastructure and Growth: Empirical Evidence, July 2009

2701 Felix Bierbrauer, Optimal Income Taxation and Public Goods Provision in a Large Economy with Aggregate Uncertainty, July 2009

2702 Marc Gronwald, Investigating the U.S. Oil-Macroeconomy Nexus using Rolling Impulse Responses, July 2009

2703 Ali Bayar and Bram Smeets, Government Deficits in the European Union: An Analysis of Entry and Exit Dynamics, July 2009

2704 Stergios Skaperdas, The Costs of Organized Violence: A Review of the Evidence, July 2009

2705 António Afonso and Christophe Rault, Spend-and-tax: A Panel Data Investigation for the EU, July 2009 
2706 Bruno S. Frey, Punishment - and beyond, July 2009

2707 Michael Melvin and Mark P. Taylor, The Crisis in the Foreign Exchange Market, July 2009

2708 Firouz Gahvari, Friedman Rule in a Model with Endogenous Growth and Cash-inadvance Constraint, July 2009

2709 Jon H. Fiva and Gisle James Natvik, Do Re-election Probabilities Influence Public Investment?, July 2009

2710 Jarko Fidrmuc and Iikka Korhonen, The Impact of the Global Financial Crisis on Business Cycles in Asian Emerging Economies, July 2009

2711 J. Atsu Amegashie, Incomplete Property Rights and Overinvestment, July 2009

2712 Frank R. Lichtenberg, Response to Baker and Fugh-Berman's Critique of my Paper, "Why has Longevity Increased more in some States than in others?", July 2009

2713 Hans Jarle Kind, Tore Nilssen and Lars Sørgard, Business Models for Media Firms: Does Competition Matter for how they Raise Revenue?, July 2009

2714 Beatrix Brügger, Rafael Lalive and Josef Zweimüller, Does Culture Affect Unemployment? Evidence from the Röstigraben, July 2009

2715 Oliver Falck, Michael Fritsch and Stephan Heblich, Bohemians, Human Capital, and Regional Economic Growth, July 2009

2716 Wladimir Raymond, Pierre Mohnen, Franz Palm and Sybrand Schim van der Loeff, Innovative Sales, R\&D and Total Innovation Expenditures: Panel Evidence on their Dynamics, July 2009

2717 Ben J. Heijdra and Jochen O. Mierau, Annuity Market Imperfection, Retirement and Economic Growth, July 2009

2718 Kai Carstensen, Oliver Hülsewig and Timo Wollmershäuser, Price Dispersion in the Euro Area: The Case of a Symmetric Oil Price Shock, July 2009

2719 Katri Kosonen and Gaëtan Nicodème, The Role of Fiscal Instruments in Environmental Policy, July 2009

2720 Guglielmo Maria Caporale, Luca Onorante and Paolo Paesani, Inflation and Inflation Uncertainty in the Euro Area, July 2009

2721 Thushyanthan Baskaran and Lars P. Feld, Fiscal Decentralization and Economic Growth in OECD Countries: Is there a Relationship?, July 2009 